\title{
Will Hydroxychloroquine Still Be a Game-Changer for COVID-19 by Combining Azithromycin?
}

\author{
Chunfeng $\mathrm{Li}^{1 *}$ and Genhong Cheng ${ }^{2 *}$ \\ 1 Institute for Immunity, Transplantation, and Infection, School of Medicine, Stanford University, Stanford, CA, United States, \\ ${ }^{2}$ Department of Microbiology, Immunology, and Molecular Genetics, University of California, Los Angeles, CA, United States
}

OPEN ACCESS

Edited by:

Ken J. Ishii,

University of Tokyo, Japan

Reviewed by:

Cevayir Coban,

University of Tokyo, Japan

Didier Raoult,

Aix-Marseille Université, France

*Correspondence:

Chunfeng $L$

chunfeng@stanford.edu

Genhong Cheng

gcheng@mednet.ucla.edu

Specialty section:

This article was submitted to Vaccines and Molecular Therapeutics,

a section of the journal

Frontiers in Immunology

Received: 07 May 2020

Accepted: 21 July 2020

Published: 07 August 2020

Citation:

Li C and Cheng G (2020) Will

Hydroxychloroquine Still Be a Game-Changer for COVID-19 by

Combining Azithromycin?

Front. Immunol. 11:1969.

do: 10.3389/fimmu.2020.01969
Recent small-scale clinical trials have shown promising results in the use of hydroxychloroquine, an FDA approved anti-malaria drug, for the treatment of COVID-19. However, large scale, randomized and double-blind clinical trials are needed to confirm the safety and efficacy of hydroxychloroquine in COVID-19 patients. Here, we review the progress of using hydroxychloroquine or chloroquine as anti-viral agents, failed clinical trials of chloroquine in treatment of dengue virus and influenza infection, and especially the mechanism of azithromycin in inhibiting viral replication, so as to shed light on the ongoing clinical trials and further researches of hydroxychloroquine on SARS-CoV-2 infected patients.

Keywords: COVID-19, SARS- CoV-2, hydroxychloroquine, azithromycin (AZM), clinical trial

As of $6 / 3 / 2020$, more than 6.3 million people across the world have been infected with SARS-CoV-2, with the death toll reaching 383,000 since the beginning of the outbreak in late December 2019 (https://coronavirus.jhu.edu/map.html). This pandemic has changed our daily life dramatically, especially of those who are directly infected. SARS-CoV-2 is a highly virulent newly emerging coronavirus belonging to the Betacoronavirus genus within the family of Coronaviridae, which includes four genera: Alphacoronavirus, Betacoronavirus, Gammacoronavirus, and Deltacoronavirus (1). SARS-CoV-2 and other four human coronaviruses (OC43, SARS-CoV, MERS-CoV, and HKU1) belong to the Betacoronavirus genus, while two other human coronaviruses NL63 and 229E, PDEV (porcine epidemic diarrhea virus) in pigs, TGEV (transmissible gastroenteritis virus) in swine, FCoV (feline coronaviruses), CCoV (canine coronaviruses), FRECV (ferret enteric coronavirus) belong to the Alphacoronavirus genus (2). Like SARS and MERS, SARS-CoV-2 was originally found in a bat reservoir, but was transmitted through a different intermediate host like pangolin (3).

\section{HYDROXYCHLOROQUINE AND CHLOROQUINE INHIBIT VIRUS INFECTION IN VITRO AND IN VIVO}

Currently there are no FDA approved drugs for COVID-19. Recently, Wang et al. reported that chloroquine can inhibit SARS-CoV-2 replication in vitro (4). Chloroquine is an FDA-approved anti-malarial drug. Hydroxychloroquine is a derivative of chloroquine. They have similar safety profiles and therapeutic effects. Hydroxychloroquine has also been widely used for the treatment of systemic lupus erythematosus (SLE) due to its anti-inflammatory function. Yao et al. found that hydroxychloroquine $\left(\mathrm{EC}_{50}=0.72 \mu \mathrm{M}\right)$ is more potent than chloroquine $\left(\mathrm{EC}_{50}=5.47 \mu \mathrm{M}\right)$ in inhibiting SARS-CoV-2 in vitro (5). It is well-established that chloroquine or hydroxychloroquine 
can inhibit different viruses in vitro, including encephalomyocarditis virus, Sindbis virus, influenza A virus, Newcastle disease virus, herpes simplex virus, vaccinia virus, VSV (6-8), also including, Chikungunya virus (CHIKV) (9), dengue virus (DENV) (10), Ebola virus (11), and the SARS-CoV (12). Our and other's data have also shown that chloroquine can suppress Zika virus (ZIKV) replication in different cells in vitro $(13-16)$.

We have also used different mouse models like Balb/c mice, Ifnar $1^{-/-}$mice, neonatal mice, and pregnant mice to confirm the in vivo activity of chloroquine in inhibiting ZIKV (13). With the pregnant mouse model, we found that orally administrated chloroquine can prevent ZIKV infection in the fetal brain and rescue microcephaly caused by ZIKV infection. Our data also demonstrated that chloroquine can inhibit ZIKV replication more efficiently when delivered soon after infection (13). In agreement with our findings, Tan et al. found that chloroquine could inhibit enterovirus EV-A71 in mice more efficiently if administered before infection (17). Chloroquine can also inhibit other viruses in vivo, including human coronavirus OC43 (18), and influenza A H5N1 (19). However, chloroquine is ineffective in inhibiting Ebola virus (11,20), Nipah virus (21), and influenza virus (22) in vivo due to multiple reasons, such as the ways and timing to administrate the drugs, the host animal model used, the replication kinetics of different viruses and so on.

\section{CLINICAL TRIALS OF HYDROXYCHLOROQUINE OR CHLOROQUINE IN PATIENTS WITH OTHER INFECTIOUS DISEASES, AND ITS IMPLICATIONS FOR COVID-19}

In a clinical trial of DENV infected patients receiving chloroquine for 3 days beginning $72 \mathrm{~h}$ after infection (Table 1), chloroquine did not reduce viremia $(23,24)$. In another clinical trial of chikungunya virus infection, patients were given $600 \mathrm{mg}$ chloroquine for the first 3 days and $300 \mathrm{mg}$ for another 2 days (Table 1). The results showed that 11 out of 27 patients from both the test and control groups were negative for viral RNA test on day 3 and all patients were negative on day 6 . Chloroquine also did not improve patient outcomes, but was associated increased risk of arthralgia at day 200 after treatment (9, 32). Finally, in a randomized, double-blind, and placebo controlled trial on the effect of chloroquine on prevention of influenza, healthy adults received chloroquine phosphate $(500 \mathrm{mg} /$ day for 1 week, then once a week for 11 weeks) or placebo were monitored for flu symptoms for 1 year (Table 1). Ultimately, 29 out of 738 (4\%) placebo and 38 out of 724 (5\%) chloroquine-treated subjects were infected with influenza (25). In these clinical trials, mild adverse events were only seen in chloroquine-treated groups.

For antiviral treatment of acute infectious disease, the therapeutic time window is a critical factor controlling patient outcomes. Based on findings from China, the median period of viral shedding is 20.0 days and could be detected up to 37 days in COVID-19 survivors (33). A study from Singapore showed that shedding of SARS-CoV-2 from nasopharyngeal aspirates of patients was detected up to 24 days after symptom onset (34). The median period from onset of symptoms to ARDS (Acute Respiratory Distress Syndrome) is around 8-11 days for COVID19 patients and the duration of fever is around 8-12 days in survivors (33), which is longer than 2-7 days for influenza, Zika, or dengue fever (35). This characteristic of COVID-19 provides a longer and better therapeutic window for antiviral drug treatment before reaching the "point of no return." To reach this goal, early diagnosis and fast testing, which means a turn-around time of $<24 \mathrm{~h}$, are "bottlenecks" for most of hospitals in the midst of the crisis, especially for developing countries that do not have enough detection equipment, reagents, and professionals.

\section{CLINICAL TRIALS OF HYDROXYCHLOROQUINE OR CHLOROQUINE IN COVID-19 PATIENTS}

Recently, Yao et al. found that, based on the difference of $\mathrm{IC}_{50}$ of hydroxychloroquine and chloroquine to SARS-CoV-2, the predicted physiologically-based pharmacokinetics (PBPK) of hydroxychloroquine in the human lung are more advantageous than those of chloroquine in inhibiting SARS-CoV-2 in vivo. As a result, hydroxychloroquine was suggested in clinical trials to combat COVID-19 by the authors (5). In a preprint manuscript, Chen et al. tested the efficacy of hydroxychloroquine $[400 \mathrm{mg} / \mathrm{d}$ ( $200 \mathrm{mg} / \mathrm{bid}$ ) between day 1 and 5] with 31 patients, and another randomized 31 patients served as controls (Table $\mathbf{1}$ ). The patients were enrolled after positive RT-PCR test and CT scan with pneumonia. Control patients received standard treatment only. Body temperature recovery time (2.2 vs. 3.2 days) and cough remission time (2.0 vs. 3.1 days) were significantly reduced in hydroxychloroquine treated patients (28). Gautret et al. also evaluated the efficacy of hydroxychloroquine on COVID19 patients (Table 1). In their trial, 20 patients in Marseille were orally administrated hydroxychloroquine sulfate $200 \mathrm{mg}$, three times per day for 10 days soon after testing positive for SARS-CoV-2, while 16 patients from Marseille or other nearby cities who refused the treatment served as controls. Six patients out of the 20 hydroxychloroquine-treated patients also received azithromycin (AZM) orally (500 $\mathrm{mg}$ on day 1 followed by $250 \mathrm{mg}$ per day for another 4 days) to prevent bacterial infection. Six days later, all patients who received hydroxychloroquine and azithromycin tested negative for SARSCoV-2 by RT-PCR (virologic cure), while $57.1 \%$ of patients treated with hydroxychloroquine, and $12.5 \%$ in the control group were negative (29). They also showed in another clinical study of 80 COVID-19 patients that hydroxychloroquine combined with AZM could reduce nasopharyngeal viral load significantly (83\% negative at Day 7, around 12 days post-onset of symptoms, and $93 \%$ at Day 8 tested by RT-PCR) (Table 1) (30), compared to median 20 days of viral shedding in other COVID-19 patients $(33,34)$. In contrast, there are other small clinical trials showing hydroxychloroquine alone or combined with azithromycin could not improve viral suppression or outcomes in COVID-19 patients $(36,37)$. However, these cohorts are very 
TABLE 1 | Clinical trials of hydroxychloroquine or chloroquine w/o azithromycin in patients with infectious disease

\begin{tabular}{|c|c|c|c|c|c|c|}
\hline Drug & Target & Treatment & Duration & Trial design & Patient outcome & References \\
\hline Chloroquine & DENV & $\begin{array}{l}\text { The regimen for CQ was } 600 \mathrm{mg} \text { base ( } 4 \\
\times 150 \mathrm{mg} \text { tablets) on enrolment to the } \\
\text { study, then } 600 \mathrm{mg} \text { on day } 2 \text { and } 300 \mathrm{mg} \\
\text { on day } 3\end{array}$ & 3 days & $\begin{array}{l}\text { Randomized, double blind, placebo } \\
\text { controlled; } \\
\text { CQ }(n=153) \text { or placebo }(n=154)\end{array}$ & $\begin{array}{l}\text { Time to resolution of DENV viraemia } \\
\text { and time to resolution of DENV NS1 } \\
\text { antigenaemia; } \\
\text { fever clearance time; dengue } \\
\text { hemorrhagic fever }\end{array}$ & (23) \\
\hline Chloroquine & DENV & $500 \mathrm{mg}$ chloroquine (300 mg base) BID & 3 days & $\begin{array}{l}\text { Randomized, double blind, placebo } \\
\text { controlled; } \\
\mathrm{CQ}(n=9) \text { or placebo }(n=18)\end{array}$ & $\begin{array}{l}\text { Duration of the disease or the degree } \\
\text { and days of fever }\end{array}$ & (24) \\
\hline Chloroquine & Chikungunya virus & $\begin{array}{l}600 \mathrm{mg} \text { chloroquine for the first } 3 \text { days } \\
\text { and } 300 \mathrm{mg} \text { for another } 2 \text { days }\end{array}$ & 5 days & $\begin{array}{l}\text { Randomized, double blind, placebo } \\
\text { controlled; } \\
C Q(n=27) \text { or placebo }(n=27)\end{array}$ & $\begin{array}{l}\text { Duration of febrile arthralgia, decrease } \\
\text { of viremia; } \\
\text { arthralgia at day } 200\end{array}$ & (9) \\
\hline Chloroquine & Influenza virus & $\begin{array}{l}500 \mathrm{mg} / \text { day for } 1 \text { week, then once a week } \\
\text { for } 11 \text { weeks }\end{array}$ & 12 weeks & $\begin{array}{l}\text { Randomized, double blind, placebo } \\
\text { controlled; } \\
\mathrm{CQ}(n=724) \text { or placebo }(n=738)\end{array}$ & $\begin{array}{l}\text { Lab-confirmed influenza infection } \\
\text { defined by specific symptoms and } \\
\text { RT-PCR on nasal swabs, or a 4-fold } \\
\text { increase in HA-inhibition titres over } 12 \\
\text { weeks }\end{array}$ & (25) \\
\hline $\begin{array}{l}\text { Chloroquine w/o } \\
\text { azithromycin }\end{array}$ & P. falciparum & $\begin{array}{l}600 \mathrm{mg} \text { base }(4 \times 150 \text {-mg base tablet) of } \\
\text { chloroquine for } 2 \text { days and } 300 \mathrm{mg} \text { base } \\
(2 \times 150 \text {-mg base tablet) of chloroquine } \\
\text { on day } 3 \text {; } \\
\text { w/o } 1 \mathrm{~g}(2 \times 500 \text {-mg tablet) of } \\
\text { azithromycin; }\end{array}$ & 3 days & $\begin{array}{l}\text { Open label } \\
\text { non-randomized; } \\
n=64 \text { for combination treatment; } \\
\text { chloroquine only }(n=16) \\
\text { AZM only }(n=16)\end{array}$ & Parasite counts & (26) \\
\hline $\begin{array}{l}\text { Chloroquine and } \\
\text { azithromycin }\end{array}$ & P. falciparum & $\begin{array}{l}\text { AZM 1,000 mg and CQ 600-mg base } \\
\text { once daily for } 3 \text { days }\end{array}$ & 3 days & $\begin{array}{l}\text { Multi-Country Randomized; } \\
\mathrm{CQ} \text { and AZM combination }(N=227) \\
\text { mefloquine hydrochloride }(N=231)\end{array}$ & P. falciparum parasite clearance rate & (27) \\
\hline Hydroxychloroquine & SARS-CoV-2 & $\begin{array}{l}400 \mathrm{mg} / \mathrm{d}(200 \mathrm{mg} / \mathrm{bid}) \text { between day } 1 \\
\text { and } 5\end{array}$ & 5 days & $\begin{array}{l}\text { Randomized, } \\
\mathrm{HCQ}(n=31) \text { or placebo }(n=31)\end{array}$ & $\begin{array}{l}\text { Time to clinical recovery, clinical } \\
\text { characteristics, and radiological } \\
\text { results were } \\
\text { assessed at baseline and } 5 \text { days after } \\
\text { treatment }\end{array}$ & (28) \\
\hline $\begin{array}{l}\text { Hydroxychloroquine w/o } \\
\text { azithromycin }\end{array}$ & SARS-CoV-2 & $\begin{array}{l}\text { HCQ: } 200 \mathrm{mg} \text {, three times per day; } \\
\text { AZM: } \\
500 \mathrm{mg} \text { on day } 1 \text { followed by } 250 \mathrm{mg} \text { per } \\
\text { day for another } 4 \text { days }\end{array}$ & $\begin{array}{l}10 \text { days for } \mathrm{HCQ} \\
5 \text { days for } A Z M\end{array}$ & $\begin{array}{l}\text { Open label } \\
\text { non-randomized; } \\
\text { HCQ }(n=20) \text { or placebo }(n=16) ; \\
6 \text { patients from HCQ group also } \\
\text { received azithromycin }\end{array}$ & Viral load & (29) \\
\hline $\begin{array}{l}\text { Hydroxychloroquine and } \\
\text { azithromycin }\end{array}$ & SARS-CoV-2 & $\begin{array}{l}\text { HCQ: } 200 \mathrm{mg} \text {, three times per day; } \\
\text { AZM: } \\
500 \mathrm{mg} \text { on day } 1 \text { followed by } 250 \mathrm{mg} \text { per } \\
\text { day for another } 4 \text { days }\end{array}$ & $\begin{array}{l}10 \text { days for } \mathrm{HCQ} \\
5 \text { days for } \mathrm{AZM}\end{array}$ & $\begin{array}{l}\text { Open label } \\
\text { non-randomized; } \\
\text { All patients received combination } \\
\text { treatment }\end{array}$ & Viral load & (30) \\
\hline Chloroquine & SARS-CoV-2 & $\begin{array}{l}\text { High dose: } \\
600 \mathrm{mg} \text { CQ twice daily; } \\
\text { Low dose: } \\
450 \mathrm{mg} \text { twice daily on day } 1 \text { and once } \\
\text { daily for } 4 \text { days }\end{array}$ & $\begin{array}{l}\text { High dose for } 10 \\
\text { days; } \\
\text { Low dose for } 5 \\
\text { days }\end{array}$ & $\begin{array}{l}\text { Randomized; } \\
\text { High dose }(n=41) \text {, low dose }(n=40)\end{array}$ & Reduction in lethality & (31) \\
\hline
\end{tabular}


small, and the testing methods, patient status, and supporting care from different hospitals are different. Therefore, large-scale, randomized, double-blind, placebo controlled trials are essential to determine the efficacy and safety of hydroxychloroquine and its combination with azithromycin in controlling COVID-19. These trials are very important for patients in countries such as the United States that are currently in crisis, and countries such as India, and South Africa, which may suffer COVID-19 outbreaks in the near future. Gathering more robust data now about COVID-19 will make us more prepared in the future.

\section{AZITHROMYCIN MAY CONTRIBUTE TO HYDROXYCHLOROQUINE FUNCTION THROUGH DIFFERENT MECHANISMS}

It remains to be seen whether hydroxychloroquine combined with AZM is more effective in treating COVID-19 efficient than hydroxychloroquine alone, and the in vivo mechanisms by which this potential synergy occurs is unknown. If yes, what's the potential mechanism in vivo? AZM is a macrolide antibiotic that can broadly inhibit gram-positive and negative bacteria targeting protein synthesis of bacterial ribosomes (38). Mortality and morbidity caused by bacteria pneumonia with coinfections maybe reduced by AZM in patients infected by Spanish flu (39) and SARS-CoV-2 (33). We and other labs found that AZM can suppress Zika virus in vitro (40,41). AZM enhances the type I and type III interferon signaling pathway and its downstream interferon stimulated genes (ISGs) response triggered by Zika virus infection in vitro. Furthermore, AZM increases expression of phosphorylated TBK1 and IRF3 to prime the host cell to respond to viral infection. AZM upregulates the interferon response induced not only by ZIKV, DENV, and polyI:C (RNA), but also by polydA:dT (DNA). These data show that AZM can be used as a broad antiviral reagent (40). AZM has also been found to inhibit rhinoviruses by enhancing Type I interferon (IFN-I) responses in bronchial epithelial cells $(42,43)$. Additionally, AZM has been shown to inhibit Ebola virus in vitro, however the mechanism is not understood (44). In another study, Dr. Raoult's lab showed that AZM has synergistic effects with hydroxychloroquine to inhibit Sars-CoV-2 in vitro, although the anti-SARS-CoV-2 activity of AZM alone is not very promising in this system (45). Moreover, AZM was used to treat infections with an inflammatory component due to its anti-inflammatory properties (46). With regard to pneumonia and cytokine storm in severe COVID-19 patients, the anti-inflammatory function of azithromycin, and hydroxychloroquine combined therapy can achieve better patient outcomes. AZM was found to kill senescent human fibroblasts, which may express more ACE2 and CD26 (47). ACE-2 (angiotensin-converting enzyme 2) is receptor for SARS-CoV-2, and CD26 [also known as dipeptidyl-peptidase IV (DPP4)] may interact with S protein of SARS-CoV-2 $(1,48)$. Hydroxychloroquine can reduce expression of lysosomal enzyme beta-galactosidase (Beta-Gal), a widely-recognized marker of senescence. Hydroxychloroquine can also reduce salivary and serum levels of IL-6, a key component of the senescenceassociated secretory phenotype (SASP) in chronic inflammatory diseases, such as Sjögren's syndrome (49). High levels of IL6 in plasma is also related to severe pathogenesis in COVID19 patients $(50,51)$. AZM may block SARS-CoV-2 infection through different mechanisms and have synergistic effects with hydroxychloroquine in vitro and in vivo, which needs to be investigated in future.

AZM and hydroxychloroquine have additional advantages: they are affordable for low-income populations, can be orally administered, have very good safety profiles, and very little drugdrug interactions (52). AZM belongs to FDA pregnancy category $B$ drug, meaning that animal studies showed no adverse effects on pregnancy $(53,54)$. Hydroxychloroquine and chloroquine are pregnancy category $\mathrm{C}$ drugs, meaning that there is a potential risk for the fetus based on animal studies, but if the benefits outweigh the risks, they may continue to be used during pregnancy to treat related symptoms. An acceptable safety profile was achieved by combining azithromycin 1,000 $\mathrm{mg}$ and chloroquine $620 \mathrm{mg} /$ day for 3 days in 1,446 pregnant women in sub-Saharan Africa (55). Azithromycin can suppress P. falciparum (Plasmodium falciparum) in vitro and in vivo (Table 1). In randomized clinical trials, AZM can enhance the efficacy of chloroquine for the treatment of acute uncomplicated malaria caused by $P$. falciparum in India and Africa $(26,27)$. Pharmacokinetic studies showed that after oral administration of AZM 1,000 mg/day for 3 days, the concentration of AZM in lung reaches peak concentrations of $17.85 \mu \mathrm{g} / \mathrm{g}$ (around $24 \mu \mathrm{M}$ ) (56). The half-lives of AZM in the lung and bronchial wash are 133.32 and $70.5 \mathrm{~h}$, respectively. With that concentration, AZM may inhibit SARS$\mathrm{CoV}-2$ in vitro and in vivo through the mechanisms mentioned above, which needs to be tested thoroughly in the future.

During revision of this review, prospective observational studies of safety, and efficacy of hydroxychloroquine with or w/o AZM in COVID-19 patients were conducted by different groups with different cohorts. Huang et al. showed that chloroquine is beneficial for COVID-19 patients in China (57), while Geleris et al. found that hydroxychloroquine w/o AZM was not related to either a greatly lowered or an increased risk of the composite end point of intubation or death $(58,59)$. The major differences between these two studies are that patients from the former study are much younger (average age of the patients $\sim 45$ vs. $\sim 57$ ), and fewer with severe symptoms that requires ventilation compare to those from the later study (57). While other retrospective studies found that hydroxychloroquine with or w/o AZM may be related to more mortality in COVID-19 patients $(59,60)$, which may due to the fact that hydroxychloroquine was more likely to be prescribed to patients with more severe disease under emergency use authorization. These data are also indicating that hydroxychloroquine with or w/o AZM may be beneficial for mild or moderate but not severe patients. However, we note that there are potential risks associated with hydroxychloroquine/chloroquine for cardiovascular disorders and ophthalmological damage if used at high dose, for example $600 \mathrm{mg}$ chloroquine twice daily for 10 days, which is $4-5$ times greater than the American Academy of Ophthalmology (AAO) recommendation $(31,61,62)$. As azithromycin and hydroxychloroquine can work as senolytics in vitro, we should be more cautious about cardiovascular disorder as cardiac cells 
become more senescent with aging $(63,64)$. More recently, Mercuro et al. found that hydroxychloroquine with or w/o AZM increased risk of corrected QT (QTc) prolongation and cardiac arrhythmias in COVID-19 patients (65). Combined hydroxychloroquine and AZM use should follow the physician's instructions, and cardiovascular and ophthalmological toxicity should be monitored during and after the short-term treatment, especially for older patients.

At the same time, the death toll in some countries, especially in older populations, remains very high. The efficacy of hydroxychloroquine in severe patients remains unknown. Many undergoing efforts are also focused on testing drugs like Remedesivir (ClinicalTrials.gov Identifier: NCT04292899) (66), HIV inhibitors (Favipiravir) (67), IL-6 antibodies [Actemra ${ }^{\circledR}$ (tocilizumab), NCT04320615], plasma from recovered patients (68), and so on. Additionally, screening of other FDA approved drugs or drugs under clinical trials may provide us more promising drug candidates for COVID-19 $(69,70)$.

In conclusion, SARS-CoV-2 is a different and challenging pathogen in many ways. It is more contagious than SARS$\mathrm{CoV}$ and causes a higher fatality rate compared to the 1918 influenza virus. However, its long period of viral shedding and clinical symptoms like fever and cough actually provide a better therapeutic window for antiviral treatment. Smallscale clinical data has shown that hydroxychloroquine can improve patient outcomes and that concurrent azithromycin treatment may have synergistic effects. There are many different mechanisms by which AZM can contribute to the efficacy of hydroxychloroquine in vitro and in vivo, which need to be

\section{REFERENCES}

1. Wu F, Zhao S, Yu B, Chen YM, Wang W, Song ZG, et al. A new coronavirus associated with human respiratory disease in China. Nature. (2020) 579:2659. doi: 10.1038/s41586-020-2008-3

2. Langel SN, Wang Q, Vlasova AN, Saif LJ. Host factors affecting generation of immunity against porcine epidemic diarrhea virus in pregnant and lactating swine and passive protection of neonates. Pathogens. (2020) 9:130. doi: 10.3390/pathogens 9020130

3. Lam TT, Shum MH, Zhu HC, Tong YG, Ni XB, Liao YS, et al. Identifying SARS-CoV-2 related coronaviruses in Malayan pangolins. Nature. (2020) 583:282-5. doi: 10.1101/2020.02.13.945485

4. Wang M, Cao R, Zhang L, Yang X, Liu J, Xu M, et al. Remdesivir and chloroquine effectively inhibit the recently emerged novel coronavirus (2019$\mathrm{nCoV}$ ) in vitro. Cell Res. (2020) 30:269-71. doi: 10.1038/s41422-020-0282-0

5. Yao X, Ye F, Zhang M, Cui C, Huang B, Niu P, et al. In vitro antiviral activity and projection of optimized dosing design of hydroxychloroquine for the treatment of severe acute respiratory syndrome coronavirus 2 (SARS-CoV-2). Clin Infect Dis. (2020) ciaa237. doi: 10.1093/cid/ciaa237

6. Inglot $\mathrm{AD}$. Comparison of the antiviral activity in vitro of some non-steroidal anti-inflammatory drugs. J Gen Virol. (1969) 4:203-14. doi: 10.1099/0022-1317-4-2-203

7. Shimizu Y, Yamamoto S, Homma M, Ishida N. Effect of chloroquine on the growth of animal viruses. Arch Gesamte Virusforsch. (1972) 36:93104. doi: 10.1007/BF01250299

8. Miller DK, Lenard J. Antihistaminics, local anesthetics, and other amines as antiviral agents. Proc Natl Acad Sci USA. (1981) 78:3605-9. doi: 10.1073/pnas.78.6.3605

9. De Lamballerie X, Boisson V, Reynier JC, Enault S, Charrel RN, Flahault A, et al. On chikungunya acute infection and chloroquine investigated carefully in the future. It is possible that different categories of patients, such as young vs. old, and mild vs. severe, may respond to hydroxychloroquine with or w/o AZM differently. Attention should be paid to the side effects of hydroxychloroquine w/o AZM in COVID-19 patients, especially in the older patients. We argue that large-scale, randomized, and double-blind clinical trials are still urgently and essentially needed to test the safety and efficacy of hydroxychloroquine w/o AZM in COVID-19 patients, and we should continue to find and test other potential treatments for COVID-19 and other emerging infectious diseases.

\section{AUTHOR CONTRIBUTIONS}

All authors listed have made a substantial, direct and intellectual contribution to the work, and approved it for publication.

\section{FUNDING}

GC was supported by NIH R01 Grant AI069120-01, UCLA CFAR grant AI028697, the UCLA AIDS Institute and UCLA David Geffen School of Medicine - Eli and Edythe Broad Center of Regenerative Medicine and Stem Cell Research Award Program.

\section{ACKNOWLEDGMENTS}

We thank Dr. Thomas Hagan (Stanford University) for constructive advice, and other lab members for helpful discussions. treatment. Vector Borne Zoonotic Dis. (2008) 8:837-9. doi: 10.1089/vbz.200 8.0049

10. Farias KJ, Machado PR, de Almeida Junior RF, de Aquino AA, da Fonseca BA. Chloroquine interferes with dengue-2 virus replication in U937 cells. Microbiol Immunol. (2014) 58:318-26. doi: 10.1111/1348-0421.12154

11. Dowall SD, Bosworth A, Watson R, Bewley K, Taylor I, Rayner E, et al. Chloroquine inhibited Ebola virus replication in vitro but failed to protect against infection and disease in the in vivo guinea pig model. J Gen Virol. (2015) 96:3484-92. doi: 10.1099/jgv.0.000309

12. Keyaerts E, Vijgen L, Maes P, Neyts J, Van Ranst M. In vitro inhibition of severe acute respiratory syndrome coronavirus by chloroquine. Biochem Biophys Res Commun. (2004) 323:264-8. doi: 10.1016/j.bbrc.2004.08.085

13. Li C, Zhu X, Ji X, Quanquin N, Deng YQ, Tian $M$, et al. Chloroquine, a FDA-approved drug, prevents Zika virus infection and its associated congenital microcephaly in mice. EBioMed. (2017) 24:189-94. doi: 10.1016/j.ebiom.2017.09.034

14. Delvecchio R, Higa LM, Pezzuto P, Valadao AL, Garcez PP, Monteiro FL, et al. Chloroquine, an endocytosis blocking agent, inhibits Zika virus infection in different cell models. Viruses. (2016) 8:322. doi: 10.1101/051268

15. Cao B, Parnell LA, Diamond MS, Mysorekar IU. Inhibition of autophagy limits vertical transmission of Zika virus in pregnant mice. J Exp Med. (2017) 214:2303-13. doi: 10.1084/jem.20170957

16. Shiryaev SA, Mesci P, Pinto A, Fernandes I, Sheets N, Shresta S, et al. Repurposing of the anti-malaria drug chloroquine for Zika Virus treatment and prophylaxis. Sci Rep. (2017) 7:15771. doi: 10.1038/s41598-017-15467-6

17. Tan YW, Yam WK, Sun J, Chu JJH. An evaluation of chloroquine as a broadacting antiviral against hand, foot and mouth disease. Antiviral Res. (2018) 149:143-9. doi: 10.1016/j.antiviral.2017.11.017

18. Keyaerts E, Li S, Vijgen L, Rysman E, Verbeeck J, Van Ranst M, et al. Antiviral activity of chloroquine against human coronavirus OC43 
infection in newborn mice. Antimicrob Agents Chemother. (2009) 53:341621. doi: 10.1128/AAC.01509-08

19. Yan Y, Zou Z, Sun Y, Li X, Xu KF, Wei Y, et al. Anti-malaria drug chloroquine is highly effective in treating avian influenza A H5N1 virus infection in an animal model. Cell Res. (2013) 23:300-2. doi: 10.1038/cr.2012.165

20. Falzarano D, Safronetz D, Prescott J, Marzi A, Feldmann F, Feldmann H. Lack of protection against ebola virus from chloroquine in mice and hamsters. Emerg Infect Dis. (2015) 21:1065-7. doi: 10.3201/eid2106.150176

21. Pallister J, Middleton D, Crameri G, Yamada M, Klein R, Hancock TJ, et al. Chloroquine administration does not prevent Nipah virus infection and disease in ferrets. J Virol. (2009) 83:11979-82. doi: 10.1128/JVI.01847-09

22. Vigerust DJ, McCullers JA. Chloroquine is effective against influenza A virus in vitro but not in vivo. Influenza Other Respir Viruses. (2007) 1:18992. doi: 10.1111/j.1750-2659.2007.00027.x

23. Tricou V, Minh NN, Van TP, Lee SJ, Farrar J, Wills B, et al. A randomized controlled trial of chloroquine for the treatment of dengue in Vietnamese adults. PLoS Negl Trop Dis. (2010) 4:e785. doi: 10.1371/journal.pntd.0000785

24. Borges MC, Castro LA, Fonseca BA. Chloroquine use improves dengue-related symptoms. Mem Inst Oswaldo Cruz. (2013) 108:596-9. doi: 10.1590/S0074-02762013000500010

25. Paton NI, Lee L, Xu Y, Ooi EE, Cheung YB, Archuleta S, et al. Chloroquine for influenza prevention: a randomised, double-blind, placebo controlled trial. Lancet Infect Dis. (2011) 11:677-83. doi: 10.1016/S1473-3099(11)70065-2

26. Dunne MW, Singh N, Shukla $M$, Valecha N, Bhattacharyya PC, Dev V, et al. A multicenter study of azithromycin, alone and in combination with chloroquine, for the treatment of acute uncomplicated Plasmodium falciparum malaria in India. J Infect Dis. (2005) 191:1582-8. doi: 10.1086/429343

27. Sagara I, Oduro AR, Mulenga M, Dieng Y, Ogutu B, Tiono AB, et al. Efficacy and safety of a combination of azithromycin and chloroquine for the treatment of uncomplicated Plasmodium falciparum malaria in two multi-country randomised clinical trials in African adults. Malar J. (2014) 13:458. doi: 10.1186/1475-2875-13-458

28. Chen Z, Hu J, Zhang Z, Jiang S, Han S, Yan D, et al. Efficacy of hydroxychloroquine in patients with COVID-19: results of a randomized clinical trial. medRxiv. (2020). doi: 10.1101/2020.03.22.20040758

29. Gautret P, Lagier JC, Parola P, Hoang VT, Meddeb L, Mailhe M, et al. Hydroxychloroquine and azithromycin as a treatment of COVID-19: results of an open-label non-randomized clinical trial. Int J Antimicrob Agents. (2020) 56:105949. doi: 10.1016/j.ijantimicag.2020.105949

30. Gautret P, Lagier JC, Parola P, Hoang VT, Meddeb L, Sevestre J, et al. Clinical and microbiological effect of a combination of hydroxychloroquine and azithromycin in 80 COVID-19 patients with at least a six-day follow up: A pilot observational study. Travel Med Infect Dis. (2020) 34:101663. doi: 10.1016/j.tmaid.2020.101663

31. Borba M, Val FdA, Sampaio VS, Alexandre MA, Melo GC, Brito M, et al. Chloroquine diphosphate in two different dosages as adjunctive therapy of hospitalized patients with severe respiratory syndrome in the context of coronavirus (SARS-CoV-2) infection: preliminary safety results of a randomized, double-blinded, phase IIb clinical trial (CloroCovid-19 Study). medRxiv. (2020). doi: 10.1101/2020.04.07.20056424

32. Roques P, Thiberville SD, Dupuis-Maguiraga L, Lum FM, Labadie K, Martinon F, et al. Paradoxical effect of chloroquine treatment in enhancing chikungunya virus infection. Viruses. (2018) 10:268. doi: 10.3390/v10050268

33. Zhou F, Yu T, Du R, Fan G, Liu Y, Liu Z, et al. Clinical course and risk factors for mortality of adult inpatients with COVID-19 in Wuhan, China: a retrospective cohort study. Lancet. (2020) 395:105462. doi: 10.1016/S0140-6736(20)30566-3

34. Young BE, Ong SWX, Kalimuddin S, Low JG, Tan SY, Loh J, et al. Epidemiologic features and clinical course of patients infected with SARS-CoV-2 in Singapore. JAMA. (2020) 323:1488-94. doi: 10.1001/jama. 2020.3204

35. Rocha BAM, Guilarde AO, Argolo A, Tassara MP, da Silveira LA, Junqueira IC, et al. Dengue-specific serotype related to clinical severity during the 2012/2013 epidemic in centre of Brazil. Infect Dis Poverty. (2017) 6:116. doi: 10.1186/s40249-017-0328-9
36. Chen J, Liu D, Liu L, Liu P, Xu Q, Xia L et al. A pilot study of hydroxychloroquine in treatment of patients with common coronavirus disease-19 (COVID-19). Zhejiang Da Xue Xue Bao Yi Xue Ban. (2020) 49:215-9. doi: 10.3785/j.issn.1008-9292.2020.03.03

37. Molina JM, Delaugerre C, Goff JL, Mela-Lima B, Ponscarme D, Goldwirt L, et al. No evidence of rapid antiviral clearance or clinical benefit with the combination of hydroxychloroquine and azithromycin in patients with severe COVID-19 infection. Med Mal Infect. (2020) 50:384. doi: 10.1016/j.medmal.2020.03.006

38. Retsema J, Girard A, Schelkly W, Manousos M, Anderson M, Bright G, et al. Spectrum and mode of action of azithromycin (CP-62,993), a new 15-membered-ring macrolide with improved potency against gram-negative organisms. Antimicrob Agents Chemother. (1987) 31:193947. doi: 10.1128/AAC.31.12.1939

39. Morens DM, Taubenberger JK, Fauci AS. Predominant role of bacterial pneumonia as a cause of death in pandemic influenza: implications for pandemic influenza preparedness. I Infect Dis. (2008) 198:96270. doi: $10.1086 / 591708$

40. Li C, Zu S, Deng YQ, Li D, Parvatiyar K, Quanquin N, et al. Azithromycin protects against Zika virus infection by upregulating virus-induced Type I and III interferon responses. Antimicrob Agents Chemother. (2019) 63:e0039419. doi: 10.1128/AAC.00394-19

41. Retallack H, Di Lullo E, Arias C, Knopp KA, Laurie MT, Sandoval-Espinosa $\mathrm{C}$, et al. Zika virus cell tropism in the developing human brain and inhibition by azithromycin. Proc Natl Acad Sci USA. (2016) 113:1440813. doi: $10.1073 /$ pnas. 1618029113

42. Gielen V, Johnston SL, Edwards MR. Azithromycin induces anti-viral responses in bronchial epithelial cells. Eur Respir J. (2010) 36:64654. doi: 10.1183/09031936.00095809

43. Menzel M, Akbarshahi H, Tufvesson E, Persson C, Bjermer L, Uller L. Azithromycin augments rhinovirus-induced IFNbeta via cytosolic MDA5 in experimental models of asthma exacerbation. Oncotarget. (2017) 8:3160131. doi: $10.18632 /$ oncotarget. 16364

44. Kouznetsova J, Sun W, Martinez-Romero C, Tawa G, Shinn P, Chen CZ, et al. Identification of 53 compounds that block Ebola virus-like particle entry via a repurposing screen of approved drugs. Emerg Microbes Infect. (2014) 3:e84. doi: $10.1038 / \mathrm{emi} .2014 .88$

45. Andreani J, Le Bideau M, Duflot I, Jardot P, Rolland C, Boxberger M, et al. In vitro testing of combined hydroxychloroquine and azithromycin on SARS-CoV-2 shows synergistic effect. Microb Pathog. (2020) 145:104228. doi: 10.1016/j.micpath.2020.104228

46. Schogler A, Kopf BS, Edwards MR, Johnston SL, Casaulta C, Kieninger E, et al. Novel antiviral properties of azithromycin in cystic fibrosis airway epithelial cells. Eur Respir J. (2015) 45:428-39. doi: 10.1183/09031936.00102014

47. Ozsvari B, Nuttall JR, Sotgia F, Lisanti MP. Azithromycin and Roxithromycin define a new family of "senolytic" drugs that target senescent human fibroblasts. Aging. (2018) 10:3294-307. doi: 10.18632/aging.101633

48. Vankadari N, Wilce JA. Emerging WuHan (COVID-19) coronavirus: glycan shield and structure prediction of spike glycoprotein and its interaction with human CD26. Emerg Microbes Infect. (2020) 9:6014. doi: $10.1080 / 22221751.2020 .1739565$

49. Sargiacomo C, Sotgia F, Lisanti MP. COVID-19 and chronological aging: senolytics and other anti-aging drugs for the treatment or prevention of corona virus infection? Aging. (2020) 12:6511-7. doi: 10.18632/aging.103001

50. Chen G, Wu D, Guo W, Cao Y, Huang D, Wang H, et al. Clinical and immunological features of severe and moderate coronavirus disease 2019. J Clin Invest. (2020) 130:2620-9. doi: 10.1101/2020.02.16.20023903

51. Ruan Q, Yang K, Wang W, Jiang L, Song J. Clinical predictors of mortality due to COVID-19 based on an analysis of data of 150 patients from Wuhan, China. Intensive Care Med. (2020) 46:846-8. doi: 10.1007/s00134-020-06028-z

52. Cook JA, Randinitis EJ, Bramson CR, Wesche DL. Lack of a pharmacokinetic interaction between azithromycin and chloroquine. Am J Trop Med Hyg. (2006) 74:407-12. doi: 10.4269/ajtmh.2006.74.407

53. Sarkar M, Woodland C, Koren G, Einarson AR. Pregnancy outcome following gestational exposure to azithromycin. BMC Pregnancy Childbirth. (2006) 6:18. doi: 10.1186/1471-2393-6-18 
54. Lin KJ, Mitchell AA, Yau WP, Louik C, Hernandez-Diaz S. Safety of macrolides during pregnancy. Am J Obstet Gynecol. (2013) 208:221 e18. doi: 10.1016/j.ajog.2012.12.023

55. Kimani J, Phiri K, Kamiza S, Duparc S, Ayoub A, Rojo R, et al. Efficacy and safety of azithromycin-chloroquine versus sulfadoxine-pyrimethamine for intermittent preventive treatment of Plasmodium falciparum Malaria infection in pregnant women in Africa: an open-label, randomized trial. PLoS ONE. (2016) 11:e0157045. doi: 10.1371/journal.pone.0157045

56. Di Paolo A, Barbara C, Chella A, Angeletti CA, Del Tacca M. Pharmacokinetics of azithromycin in lung tissue, bronchial washing, and plasma in patients given multiple oral doses of 500 and $1000 \mathrm{mg}$ daily. Pharmacol Res. (2002) 46:545-50. doi: 10.1016/S1043661802 002384

57. Huang M, Li M, Xiao F, Liang J, Pang P, Tang T, et al. Preliminary evidence from a multicenter prospective observational study of the safety and efficacy of chloroquine for the treatment of COVID-19. medRxiv. (2020). doi: 10.1101/2020.04.26.20081059

58. Geleris J, Sun Y, Platt J, Zucker J, Baldwin M, Hripcsak G, et al. Observational study of hydroxychloroquine in hospitalized patients with Covid-19. N Engl J Med. (2020) 382:2411-8. doi: 10.1056/NEJMoa2012410

59. Rosenberg ES, Dufort EM, Udo T, Wilberschied LA, Kumar J, Tesoriero J, et al. Association of treatment with hydroxychloroquine or azithromycin with in-hospital mortality in patients with COVID-19 in New York state. JAMA. (2020) 323:2493-502.doi: 10.1001/jama.2020.8630

60. Magagnoli J, Narendran S, Pereira F, Cummings T, Hardin JW, Sutton SS, et al. Outcomes of hydroxychloroquine usage in United States veterans hospitalized with Covid-19. Med (NY). (2020). doi: 10.1016/j.medj.2020. 06.001

61. Marmor MF. COVID-19 and Chloroquine/Hydroxychloroquine: is there ophthalmological concern? Am J Ophthalmol. (2020) 213:A3-4. doi: 10.1016/j.ajo.2020.03.029

62. Joyce E, Fabre A, Mahon N. Hydroxychloroquine cardiotoxicity presenting as a rapidly evolving biventricular cardiomyopathy: key diagnostic features and literature review. Eur Heart J Acute Cardiovasc Care. (2013) 2:7783. doi: $10.1177 / 2048872612471215$
63. Ray WA, Murray KT, Hall K, Arbogast PG, Stein CM. Azithromycin and the risk of cardiovascular death. N Engl J Med. (2012) 366:188190. doi: 10.1056/NEJMoa1003833

64. Shimizu I, Minamino T. Cellular senescence in cardiac diseases. J Cardiol. (2019) 74:313-9. doi: 10.1016/j.jjcc.2019.05.002

65. Mercuro NJ, Yen CF, Shim DJ, Maher TR, McCoy CM, Zimetbaum PJ, et al. Risk of QT Interval prolongation associated with use of hydroxychloroquine with or without concomitant azithromycin among hospitalized patients testing positive for coronavirus disease 2019. (COVID-19). JAMA Cardiol. (2020) e201834. doi: 10.1001/jamacardio.2020.1834

66. Grein J, Ohmagari N, Shin D, Diaz G, Asperges E, Castagna A, et al. Compassionate use of remdesivir for patients with severe Covid-19. N Engl J Med. (2020) 382:2327-36. doi: 10.1056/NEJMoa2007016

67. Lu CC, Chen MY, Chang YL. Potential therapeutic agents against COVID-19: what we know so far. J Chin Med Assoc. (2020) 83:5346. doi: 10.1097/JCMA.0000000000000318

68. Shen C, Wang Z, Zhao F, Yang Y, Li J, Yuan J, et al. Treatment of 5 critically Ill patients with COVID-19 with convalescent plasma. JAMA. (2020) 323:1582-9. doi: 10.1001/jama.2020.4783

69. Gates B. Responding to Covid-19 - a once-in-a-century pandemic? N Engl J Med. (2020) 382:1677-9. doi: 10.1056/NEJMp2003762

70. Martinez MA. Compounds with therapeutic potential against novel respiratory. coronavirus. Antimicrob Agents Chemother. (2019) 64:17. doi: 10.1128/AAC.00399-20

Conflict of Interest: The authors declare that the research was conducted in the absence of any commercial or financial relationships that could be construed as a potential conflict of interest.

Copyright $\odot 2020 \mathrm{Li}$ and Cheng. This is an open-access article distributed under the terms of the Creative Commons Attribution License (CC BY). The use, distribution or reproduction in other forums is permitted, provided the original author(s) and the copyright owner(s) are credited and that the original publication in this journal is cited, in accordance with accepted academic practice. No use, distribution or reproduction is permitted which does not comply with these terms. 